\title{
Working across cultures in indigenous science education.
}

\author{
Unpublished Ph.D thesis, Faculty of Education, University of Waikato. \\ Michael Michie \\ The University of Waikato
}

This research considers the ability of westerners, primarily teachers, to work crossculturally with indigenous students Australia, New Zealand, Canada and the USA. It looks particularly at identity learning as a way in which westerners enhance their understanding and attitudes to another culture. Identity learning, and culture shock as an associated process, is examined in relation to the ideas of border crossing and culture brokerage.

A number of issues were raised which became foci for the research. Examination of border crossing indicated that some westerners were successful as cross-cultural communicators but did not suggest why. Discussions of cultural borders gave rise to their critique as being essentialised but failed to suggest how this was to be overcome. Anthropological models did not give any characterisation to the role of culture broker, although the ethnohistory literature gave some insight. The influence of culture shock on westerners working in indigenous communities in the settler states was not particularly understood nor its relationship to identity learning explored.

A qualitative methodology is used, involving a series of interviews with eight participants who were considered to be experienced in cross-cultural communication with a background in education. From the interviews a series of narratives were written which revealed their experiences and understandings, particularly about their border crossings, culture brokerage and opinions regarding teaching indigenous students and teaching them science. These narratives became the major source of data for analysis.

This research shows that many westerners who are successful working in crosscultural settings value the culture of their indigenous hosts. This is the consequence of enhanced identity learning and can be the result of culture shock. Not all westerners learn to value the other culture and may either leave the community or stay for some other reason. Border crossers are able to think beyond the limitations of an essentialised "we and they" dichotomy and locate themselves in other ways relative to the border. Culture brokerage is a strategy that individuals choose to use. The characteristics of an effective culture broker are those of a border crosser, establishing a nexus between border crossing and culture brokerage. 
Suggestions regarding preparation to teach in indigenous communities reflect the enhancement of identity learning and promotion of border crossing. Pre-service training should include experience practicum teaching with indigenous students. Effective teaching of indigenous students could be supported by hiring experienced teachers and extending their stays. Teachers who go to work in indigenous communities need to be aware of culture shock and its possible impact and mechanisms for minimising its impact need to be established through mentoring programmes. The students' context needs to be taken into account by consideration of their culture and appropriate interpretation of the curriculum and implementation of teaching strategies. Teachers need to acknowledge that they are in positions of power, but need to negotiate that respectfully with their indigenous students. As teachers of science, they need to have a more inclusive idea of the nature of science so they can facilitate the border crossings of their indigenous students. 